\title{
Article \\ Comparative Efficiency of Native Insect Pollinators in Reproductive Performance of Medicago sativa L. in Pakistan
}

\author{
Abdur Rauf ${ }^{1, *}\left(\mathbb{0}\right.$, Shafqat Saeed ${ }^{1, *}$, Mudssar Ali ${ }^{1}$ and Muhammad Hammad Nadeem Tahir ${ }^{2}$ \\ 1 Institute of Plant Protection, Faculty of Agriculture and Environmental Sciences, \\ MNS University of Agriculture, Multan 60000, Pakistan; mudssar.ali@mnsuam.edu.pk \\ 2 Institute of Plant Breeding and Biotechnology, Faculty of Agriculture and Environmental Sciences, \\ MNS University of Agriculture, Multan 60000, Pakistan; hammad.nadeem@mnsuam.edu.pk \\ * Correspondence: rauf2009ag581@gmail.com (A.R.); shafqat.saeed@mnsuam.edu.pk (S.S.); \\ Tel.: +92-30063-58432 (S.S.)
}

check for

updates

Citation: Rauf, A.; Saeed, S.; Ali, M.; Nadeem Tahir, M.H. Comparative Efficiency of Native Insect Pollinators in Reproductive Performance of Medicago sativa L. in Pakistan. Insects 2021, 12, 1029. https://doi.org/ $10.3390 /$ insects 12111029

Academic Editors: Michelle T. Fountain and Ignazio Floris

Received: 9 October 2021

Accepted: 11 November 2021

Published: 15 November 2021

Publisher's Note: MDPI stays neutral with regard to jurisdictional claims in published maps and institutional affiliations.

Copyright: (c) 2021 by the authors. Licensee MDPI, Basel, Switzerland. This article is an open access article distributed under the terms and conditions of the Creative Commons Attribution (CC BY) license (https:/ / creativecommons.org/licenses/by/ $4.0 /)$.
Simple Summary: Lucerne (Medicago sativa L.) is a cross-pollinated crop and pollination does not usually take place until the sexual column is released. The discharge of the sexual column is referred to as 'tripping' the flower. In this study, several bee species were investigated to facilitate the pollination of lucerne crop with a purpose to examine the pollination efficiencies of native insect pollinators that lead to a seed set of alfalfa. We designed a two-year field trial to investigate the abundance and diversity of insect pollinators along with foraging behavior in terms of stay time, visitation rate, pollen harvest and tripping efficiency. Moreover, the single-visit efficiency in terms of number of seeds per pod, germination and seed yield was evaluated. Ten major pollinators (five solitary bees, three honeybees and two flies) were tested for their pollination efficiency as effective pollinators. Findings show the solitary bees (Megachile cephalotes, Megachile hera, Amegilla sp.) can be recommended as an effective pollinator for this crop, thus increasing options available to seed growers. For lucerne seed development, more consideration should be paid to the variety of native wild bees, conservation strategies and foraging requirements in establishing a diverse pollination system rather than a single bee species.

Abstract: Lucerne (Medicago sativa L.) is a cross-pollinated crop and requires entomophilous pollination for tripping of flowers and subsequent pod and seed set. To discover the best pollinators for lucerne seed production, a two-year field trial was carried out at the research farm of MNS University of Agriculture, Multan, Pakistan. Abundance and diversity of insect pollinators along with the foraging behavior were recorded in terms of tripping efficiency, stay time, visitation rate and pollen harvest. The single-visit efficiency of abundant insect pollinators was also evaluated in terms of number of seeds and seed weight per raceme along with germination percentage. Ten most abundant floral visitors (five solitary bee species, three honeybee species and two syrphid fly species) were tested for their pollination efficiency. Honeybees were most abundant in both the years followed by the solitary bees and syrphid flies. Single-visit efficacy in terms of number of pods per raceme, number of seeds per raceme, 1000 seed weight and germination percentage revealed Megachile cephalotes as the most efficient insect pollinator followed by Megachile hera and Amegilla sp. Future studies should investigate the biology and ecology of these bee species with special emphasis on their nesting behavior and seasonality.

Keywords: solitary bees; honeybees; syrphid flies; visitation rate; single visit efficacy

\section{Introduction}

Insect pollination is essential for the sustainability of both agricultural and natural ecosystems since $87 \%$ of flowering plants and nearly $35 \%$ of crops worldwide are dependent on insect and other pollinators [1,2]. Bees have been reported as the most efficient among 
the insect pollinators due to their distinctive characteristics [2-4]. Both managed and wild bees provide pollination services to the vast majority of fruits, vegetables, forage crops (alfalfa and clovers), oil-producing crops [5] and wild flowering plants [6].

Lucerne, also known as alfalfa (Medicago sativa L.), is a cross-pollinated crop. Because of its high nutritional content, adaptability, good quality characteristics and herbage yield, it is one of the most valuable source as fodder grown in more than 80 countries [7-13]. Pollination is a key limitation in alfalfa seed production.

The lucerne flower has a standard petal on which bees often land, as well as two smaller wing petals on each side. These keel petals exert significant pressure on the female sexual column. The flower of alfalfa is pollinated unless the keel is forced to open i.e., the release of sexual column. The discharge of the sexual column is referred to as 'tripping' the flower [14]. Lucerne flowers need visiting bees to trip the sexual column, allowing for eventual pod and seed set [15-17]. Due to their unique floral structure and pollination requirements, a wide array of insect pollinators have been reported to visit lucerne flowers, including bees e.g., Apis cerana, A. florea, A. dorsata, Xylocopa sp.; Megachile lanata, M. rotundata, M. bicolor; M. abluta, Nomia melanderi, Andrena lebedevi and flies, e.g., Eristalinus megacephalus, E. obliquus [18-26]. However, honeybees cannot pollinate lucerne flowers effectively $[27,28]$. This inefficiency of honeybees in lucerne pollination is because of some adaptive behavioral characters, its side feeding habit for only nectar foraging and lucerne pollen lacking the essential amino acid, isoleucine [29-33].

Reproductive success in lucerne is influenced significantly by pollinator abundance, their foraging behavior and pollination characteristics (through the provision of pollen and nectar) [22,26,34-37]. Single-visit seed set is an important parameter for assessing the effectiveness of insect pollinators [38-42]. Some behavioral and morphological parameters such as stay time or visit duration and pollen load affect yield attributes [29]. The efficiency of bees can be assessed in terms of seed set after their single visits [43,44]. Lucerne seed production can be obtained through commercially available bees (Megachile rotundata F. and Nomia melanderi Cockerell) or through available native bees around the world [15]. Only a few studies have reported biodiversity of native pollinators and their role in reproductive success (seed set) of lucerne $[15,26,45]$, while no previous study has reported the single-visit seed set efficiency of native insect pollinators for lucerne seed production.

The purpose of this study was to assess the biodiversity of native insect pollinators (i.e., solitary bees, honeybees and flies) along with comparing their pollination efficiency in order to find the best native pollinators for lucerne seed production.

\section{Materials and Methods}

\subsection{Study Site and Experiment Design}

This study was conducted at the experimental farm of MNS University of Agriculture, Multan (longitude $71^{\circ} 26^{\prime} 35.5^{\prime \prime}$ E and latitude $30^{\circ} 08^{\prime} 50.5^{\prime \prime} \mathrm{N}$ ), Punjab, Pakistan. The climate of Multan is sub-tropical (arid and semi-arid) with hot summers and cold winters with low rainfall [46]. The maximum and minimum mean temperatures in summer are $42{ }^{\circ} \mathrm{C}$ and $29^{\circ} \mathrm{C}$, respectively, while these are $21^{\circ} \mathrm{C}$ and $4.5^{\circ} \mathrm{C}$ in winter, respectively. The average annual rainfall is around $186 \mathrm{~mm}$, with the majority of occurrence during the monsoon season from July to September $[47,48]$. The soil of the area is classified as sandy loam that is mildly alkaline and well-drained [49]. The lucerne cultivar 'Sargodha 2000' was sown on an area of one acre during November in both the years (2019 and 2020). The row-to-row spacing was maintained at $30-45 \mathrm{~cm}$. All the standard cultural practices were used in the experimental plot except the use of any pesticides [50].

\subsection{Study Plant Species}

Lucerne is widely grown in Pakistan as a fodder crop in different districts of Punjab and Sindh provinces. It is a perennial outcrossed open-pollinated legume pollinated by insects. Flowers are bisexual, with four petals and ten stamens arranged into racemes, and a plant can support several stems, each with multiple racemes and flowers [16,51]. 
Individual flowers remain open for a week if no pollination occurs and multi-seeded pods will mature six weeks after pollination. The peak bloom occurs between April and June in South Punjab, Pakistan [52].

\subsection{Diurnal Abundance of Insect Pollinators}

To measure the abundance of insect pollinators, three quadrats were randomly selected by throwing one square meter wooden frame during the blossom period of alfalfa. Counts were taken once a week at three-hour intervals throughout the day, starting from 8:00 am to 17:00 pm across the whole flowering season (April-June). During each time interval, a quadrat (one square meter) was observed for five-minute and all the insect visits were counted [53]. All the bee specimens were first morphotyped and then identified on wings during data recording. We also observed many other flower visitors, which did not come under systematic observation. Insect specimens were identified to the lowest taxonomic level by the experts (see Acknowledgments). All the voucher specimens were preserved and submitted to the Agricultural Museum of the Faculty of Agriculture and Environmental Sciences, MNS- University of Agriculture, Multan, Pakistan.

\subsection{Foraging Behavior of Insect Pollinators}

The tripping efficiency of abundant insect pollinators was observed in terms of the following parameters: the number of virgin flowers tripped per raceme, flowers visited but not tripped per raceme, and visiting already tripped flowers per raceme $[15,24]$. The number of flowers visited by a pollinator whose stigmas and anthers released from the keel (referred to as the tripping). The weekly data were recorded throughout the flowering season at 8:00, 11:00, 14:00 and 17:00 h.

Pollen harvest was carried out early in the morning. The buds were caged one day before their opening with a nylon mesh bag. These fully opened flowers were uncaged and visiting individuals were captured after a single visit. The pollen grains were counted in the laboratory under a stereo-zoom microscope by hemocytometric method [54].

Moreover, visitation rate (numbers of raceme visited/60 s) and stay time (the time spent per single raceme) of insect pollinators was also recorded. Weekly observations were carried out at 8:00, 11:00, 14:00 and 17:00 h, since different insects had different diurnal dynamics [55-58].

\subsection{Single-Visit Seed Set Efficiency}

For measuring single-visit seed set efficiency, some unopened floral racemes were caged with nylon mesh bags $(15 \times 7 \mathrm{~cm})$ before their opening. Upon opening of flowers, the mesh bags were removed and an individual of a specific pollinator species was allowed to land on the raceme and to visit the flowers. The racemes were re-caged after the insect visit and the un-tripped flowers were removed. Ten single visits were made for each pollinator species. Some flowers were also manually pollinated/tripped by using experimental hand pollination. The resultant reproductive success was recorded in terms of number of seeds per raceme, seed weight per raceme and germination percentage. Fifty open-pollinated (unrestricted insect visitation) flowers and 50 caged (no insect visitation) flowers were also maintained for the comparison. The resultant seeds were subjected to germination test by placing all seeds on moist filter paper in a Petri dish at room temperature, and germination was checked four days later [59].

\subsection{Data Analysis}

Data regarding pollination effectiveness of different species in terms of tripping, pollen harvest, foraging behavior (in terms of visitation rate and stay time) and single visit efficiency of abundant insect pollinator (in terms of number of pods per raceme, number of seeds set per raceme, 1000 seed weight) and germination (\%) were initially tested for normality as the basic assumption of ANOVA is that error of the model should be distributed normally. By using QQ-plot and normality test, we did not find this assumption 
to be met for our data. So, we used nonparametric methods to test the mean equality. These methods are based upon ranking of the mean. Thus, we used Kruskal-Wallis test for analysis the data followed by Conover-Iman post-hoc test as corresponding Kruskal-Wallis null hypothesis were rejected. Data were analyzed by using computer software XLSTAT (XLSTAT. 2014 version: 5.03).

\section{Results}

\subsection{Pollinator Community/Floral Visitor Census}

In this study, honeybees were most abundant followed by solitary bees and flies in both years. Apidae was the dominant family with five species, followed by two species of Megachilidae and a single species from the Halictidae. The pollinator community of lucerne was composed of 16 bee (Hymenoptera) species and six true fly (Diptera) species. A smaller proportion of these species was found during our systematic observations, i.e., five solitary bee species, three honeybees and two true fly species. Among the bees Megachile bicolor, Megachile lanata, Pseudapis sp., Xylocopa fenestrata, Xylocopa basalis, Halictus sp., Ceratina (Pithitis) smaragdula and Andrena sp. whereas, among flies Eristalinus laetus, E. megacephalus, Chrysomya rufifacies and Musca domestica were rarely seen.

The Amegilla sp., Eucera sp., Nomia (Hoplonomia) sp., Megachile hera and M. cephalotes were the most abundant visitors during both the studied years. Among solitary bees Eucera sp. and M. cephalotes were the most frequent floral visitors with totals of 215 and 206 individuals, respectively for both years. The average visitation frequency was also highest among all the observed bee species: $(0.029,0.042)$ and $(0.022,0.047)$ individuals per square meter per minute for the year 2019 and 2020, respectively (Table 1).

Table 1. Insect species in Medicago sativa L., with their total abundance and visitation frequency.

\begin{tabular}{|c|c|c|c|c|c|c|c|}
\hline Order & $\begin{array}{c}\text { Pollinator } \\
\text { Group }\end{array}$ & Family & Genus/Species & $\begin{array}{c}\text { Total } \\
\text { Abundance } \\
\text { (2019) }\end{array}$ & $\begin{array}{c}\text { Total } \\
\text { Abundance } \\
\text { (2020) }\end{array}$ & $\begin{array}{c}\text { Visitation } \\
\text { Frequency } \\
\text { (Individuals/m²/ } \\
\text { min) } \\
2019\end{array}$ & $\begin{array}{c}\text { Visitation } \\
\text { Frequency } \\
\text { (Individuals } / \mathrm{m}^{2} / \\
\text { min) } \\
2020\end{array}$ \\
\hline \multirow{7}{*}{ Hymenoptera } & \multirow[t]{4}{*}{ Solitary bees } & Apidae & $\begin{array}{c}\text { Amegilla sp. } \\
\text { Eucera sp. }\end{array}$ & $\begin{array}{l}67 \pm 3.71 \\
88 \pm 7.27\end{array}$ & $\begin{array}{c}93 \pm 5.98 \\
127 \pm 8.26\end{array}$ & $\begin{array}{l}0.022 \\
0.029\end{array}$ & $\begin{array}{l}0.031 \\
0.042\end{array}$ \\
\hline & & Halictidae & $\begin{array}{c}\text { Nomia } \\
\text { (Hoplonomia) sp. }\end{array}$ & $23 \pm 1.18$ & $71 \pm 1.25$ & 0.008 & 0.024 \\
\hline & & \multirow[t]{2}{*}{ Megachilidae } & $\begin{array}{l}\text { Megachile } \\
\text { cephalotes }\end{array}$ & $65 \pm 2.21$ & $141 \pm 11.11$ & 0.022 & 0.047 \\
\hline & & & M. hera & $77 \pm 6.63$ & $116 \pm 8.38$ & 0.026 & 0.039 \\
\hline & \multirow{3}{*}{ Honeybees } & \multirow{3}{*}{ Apidae } & Apis mellifera & $75 \pm 10.38$ & $132 \pm 2.48$ & 0.025 & 0.044 \\
\hline & & & A. dorsata & $165 \pm 5.44$ & $181 \pm 7.30$ & 0.060 & 0.054 \\
\hline & & & A. florea & $227 \pm 14.45$ & $245 \pm 14.72$ & 0.082 & 0.044 \\
\hline \multirow{2}{*}{ Diptera } & \multirow{2}{*}{ Flies } & \multirow{2}{*}{ Syrphidae } & Eristalinus aeneus & $207 \pm 13.05$ & $274 \pm 13.73$ & 0.069 & 0.091 \\
\hline & & & E. arvorum & $130 \pm 3.28$ & $182 \pm 4.13$ & 0.043 & 0.061 \\
\hline
\end{tabular}

Apis florea was most abundant (472) among honeybees while Eristalinus aeneus was the most frequent floral visitor (481) among the flies during both years studied. Diurnal dynamic patterns revealed the peak abundance of all the insect pollinator groups was attained at 11:00 am to 14:00 pm followed by a gradual decline until 17:00 pm during both years (Figure 1). 




(a)



(b)

Figure 1. Diurnal dynamic pattern of solitary bees, honeybees and flies in lucerne fields in MNSUAM, Pakistan, during (a) 2019, (b) 2020 .

\subsection{Pollination Effectiveness}

There was a difference among the three pollinator groups in terms of their tripping efficiency (chi-square $=32.69, \mathrm{DF}=39, p=0.0000$ ) and also visiting already tripped flowers (chi-square $=32.09, \mathrm{DF}=39, p=0.0000$ ). Tripping efficiency of solitary bees was higher 
than the honeybees and flies. Flies and honeybees preferred to visit the already tripped or open flowers during their foraging.

Pollinator species varied with respect to single visit pollen harvest from the lucerne flowers (chi-square $=74.18, \mathrm{DF}=9, p=0.0000$ ). The pollen harvest was found to be highest for two Megachile species (M. cephalotes and M. hera) followed by three honeybee species (A. mellifera, A. dorsata and A. florea) while it was lowest for syrphid fly (E. aeneus) (Table 2).

Table 2. Comparison of means of ranks of pollination effectiveness in terms of tripping and pollen harvest.

\begin{tabular}{|c|c|c|c|}
\hline Pollinator Species & $\begin{array}{c}\text { Number of Virgin Flowers } \\
\text { Tripped/Raceme } \\
(N=40)\end{array}$ & $\begin{array}{l}\text { Number of Already Tripped } \\
\text { Flowers Visited/Raceme } \\
(N=40)\end{array}$ & $\begin{array}{l}\text { Number of Pollen Grains } \\
\text { Harvested in Single Visit } \\
\qquad(N=10)\end{array}$ \\
\hline Amegilla sp. & $\begin{array}{c}31.63 \mathrm{a}^{*} \\
(58.51 \pm 5.65) * *\end{array}$ & $\begin{array}{c}8.50 \mathrm{f} \\
(0.61 \pm 0.10)\end{array}$ & $\begin{array}{c}32.81 \mathrm{c} \\
(102.63 \pm 4.59)\end{array}$ \\
\hline Eucera sp. & $\begin{array}{c}32.25 \mathrm{a} \\
(62.50 \pm 5.46)\end{array}$ & $\begin{array}{c}8.25 \text { ef } \\
(0.75 \pm 0.31)\end{array}$ & $\begin{array}{c}28.38 c \\
(91.63 \pm 5.31)\end{array}$ \\
\hline Nomia (Hoplonomia) sp. & $\begin{array}{c}29.63 \mathrm{a} \\
(56.79 \pm 3.94)\end{array}$ & $\begin{array}{c}15.00 \text { def } \\
(1.00 \pm 0.00)\end{array}$ & $\begin{array}{c}24.31 \mathrm{~cd} \\
(79.25 \pm 7.12)\end{array}$ \\
\hline Megachile cephalotes & $\begin{array}{c}31.75 \mathrm{a} \\
(59.29 \pm 6.31)\end{array}$ & $\begin{array}{c}8.13 \mathrm{~d} \\
(1.25 \pm 0.13)\end{array}$ & $\begin{array}{c}72.81 \mathrm{a} \\
(1012.88 \pm 19.36)\end{array}$ \\
\hline M. hera & $\begin{array}{c}27.25 \mathrm{a} \\
(55.24 \pm 3.56)\end{array}$ & $\begin{array}{c}12.88 \mathrm{de} \\
(1.04 \pm 0.08)\end{array}$ & $\begin{array}{c}72.19 a \\
(1007.63 \pm 19.76)\end{array}$ \\
\hline Apis mellifera & $\begin{array}{c}9.75 \mathrm{~b} \\
(10.12 \pm 0.84)\end{array}$ & $\begin{array}{c}29.50 \mathrm{~b} \\
(2.25 \pm 0.22)\end{array}$ & $\begin{array}{c}53.38 \mathrm{~b} \\
(725.50 \pm 17.00)\end{array}$ \\
\hline A. dorsata & $\begin{array}{c}16.13 \mathrm{~b} \\
(9.05 \pm 2.67)\end{array}$ & $\begin{array}{c}26.25 \mathrm{c} \\
(1.75 \pm 0.18)\end{array}$ & $\begin{array}{c}51.75 \mathrm{~b} \\
(715.38 \pm 15.06)\end{array}$ \\
\hline A. florea & $\begin{array}{c}7.50 \mathrm{~b} \\
(3.57 \pm 0.00)\end{array}$ & $\begin{array}{c}28.75 c \\
(1.79 \pm 0.14)\end{array}$ & $\begin{array}{c}52.38 \mathrm{~b} \\
(717.50 \pm 12.82)\end{array}$ \\
\hline Eristalinus aeneus & $\begin{array}{c}11.63 \mathrm{~b} \\
(1.40 \pm 0.68)\end{array}$ & $\begin{array}{c}30.88 \mathrm{a} \\
(3.18 \pm 0.28)\end{array}$ & $\begin{array}{c}6.38 \mathrm{e} \\
(16.62 \pm 2.00)\end{array}$ \\
\hline E. arvorum & $\begin{array}{c}7.50 \mathrm{~b} \\
(3.57 \pm 0.00)\end{array}$ & $\begin{array}{c}36.88 \mathrm{~b} \\
(2.54 \pm 0.15)\end{array}$ & $\begin{array}{c}10.63 \mathrm{de} \\
(21.75 \pm 1.75)\end{array}$ \\
\hline Chi-Square & 32.69 & 32.09 & 74.18 \\
\hline$p$ & 0.0000 & 0.0000 & 0.0000 \\
\hline
\end{tabular}

${ }^{*}$ Means of ranks in columns having different letters are statistically significant at $\alpha=0.05 .{ }^{* *}$ Mean values with standard errors are given in parenthesis.

The probabilities of tripping flowers change over time: more flowers were tripped by pollinators on an inflorescences at 11:00 am (33.63 \pm 4.45$)$ and by 8:00 am (33.87 \pm 3.73$)$ while no difference was observed between 14:00 $\mathrm{pm}$ and 17:00 pm. Moreover, pollinator visits to already tripped flowers were higher at all times of the day except at 17:00 am as shown in Table 3.

Table 3. Comparison of means of ranks regarding tripping and already tripping per raceme (time wise).

\begin{tabular}{|c|c|c|}
\hline Time & $\begin{array}{c}\text { Number of Virgin Flowers } \\
\text { Tripped/Raceme }\end{array}$ & $\begin{array}{c}\text { Number of Already Tripped Flowers } \\
\text { Visited/Raceme) }\end{array}$ \\
\hline 8:00 & $\begin{array}{c}20.20 \mathrm{ab} * \\
(33.87 \pm 3.73) * *\end{array}$ & $\begin{array}{c}19.15 \mathrm{bc} \\
(1.51 \pm 0.19)\end{array}$ \\
\hline $11: 00$ & $\begin{array}{c}22.05 \mathrm{a} \\
(35.63 \pm 4.45)\end{array}$ & $\begin{array}{c}24.10 \mathrm{a} \\
(1.41 \pm 0.12)\end{array}$ \\
\hline $14: 00$ & $\begin{array}{c}19.85 \mathrm{~b} \\
(29.00 \pm 4.24)\end{array}$ & $\begin{array}{c}22.2 \mathrm{~b} \\
(1.77 \pm 0.15)\end{array}$ \\
\hline 17:00 & $\begin{array}{c}19.90 \mathrm{~b} \\
(29.51 \pm 3.99)\end{array}$ & $\begin{array}{c}16.55 c \\
(1.76 \pm 0.14)\end{array}$ \\
\hline Chi-Square & 0.25 & 2.44 \\
\hline$p$ & 0.969 & 0.490 \\
\hline
\end{tabular}

${ }^{*}$ Means of ranks in columns having different letters are statistically significant at $\alpha=0.05 .{ }^{* *}$ Mean values with standard errors are given in parenthesis. 


\subsection{Foraging Behavior}

The visitation rate varied among the tested pollinator species (chi-square $=22.88$, $\mathrm{DF}=9, p=0.01)$. Eucera sp. visited the maximum racemes per $60 \mathrm{~s}(13.75 \pm 1.38)$ followed by Amegilla sp. (12.40 \pm 1.38$)$ and M. cephalotes (12.32 \pm 1.41$)$.

There was a difference between the pollinators species in terms of their stay time on the raceme (chi-square $=39.39, \mathrm{DF}=9, p=0.00$ ). Eucera sp. and Nomia (Hoplonomia) sp. spent maximum time on raceme $(17.66 \pm 4.31$ and $13.70 \pm 20.3)$ followed by $A$. florea $(12.02 \pm 1.92)$ and M. hera $(10.40 \pm 1.59)$ (Table 4$)$.

Table 4. Comparison of means of ranks of foraging behavior in terms of visitation rate and stay time.

\begin{tabular}{|c|c|c|}
\hline Pollinator Species & $\begin{array}{c}\text { Visitation Rate } \\
\text { (No. of Racemes Visited/Min) } \\
(N=20)\end{array}$ & $\begin{array}{c}\text { Stay Time } \\
\text { (Time Spent (Seconds) on a } \\
\text { Raceme/Visit) } \\
(N=40)\end{array}$ \\
\hline Amegilla sp. & $\begin{array}{c}119.1 \mathrm{ab}^{*} \\
(12.40 \pm 1.38)^{* *}\end{array}$ & $\begin{array}{c}228.90 \mathrm{abc} \\
(10.07 \pm 1.06)\end{array}$ \\
\hline Eucera sp. & $\begin{array}{c}129.3 \mathrm{a} \\
(13.75 \pm 1.38)\end{array}$ & $\begin{array}{c}205.89 \mathrm{a} \\
(17.66 \pm 4.31)\end{array}$ \\
\hline Nomia (Hoplonomia) sp. & $\begin{array}{c}114.0 \mathrm{ab} \\
(12.10 \pm 1.34)\end{array}$ & $\begin{array}{c}248.44 \mathrm{ab} \\
(13.70 \pm 20.3)\end{array}$ \\
\hline Megachile cephalotes & $\begin{array}{c}105.61 \mathrm{ab} \\
(12.32 \pm 1.41)\end{array}$ & $\begin{array}{c}155.28 \mathrm{abc} \\
(9.55 \pm 2.20)\end{array}$ \\
\hline M. hera & $\begin{array}{c}115.43 \mathrm{ab} \\
(12.05 \pm 1.38)\end{array}$ & $\begin{array}{c}210.38 \mathrm{abc} \\
(10.40 \pm 1.59)\end{array}$ \\
\hline Apis mellifera & $\begin{array}{c}96.53 \mathrm{ab} \\
(10.10 \pm 1.38)\end{array}$ & $\begin{array}{c}226.99 \mathrm{abc} \\
(9.81 \pm 0.98)\end{array}$ \\
\hline A. dorsata & $\begin{array}{c}68.95 \mathrm{~b} \\
(7.55 \pm 1.38)\end{array}$ & $\begin{array}{c}213.30 \mathrm{bc} \\
(8.41 \pm 1.02)\end{array}$ \\
\hline A. florea & $\begin{array}{c}77.65 \mathrm{ab} \\
(8.10 \pm 1.38)\end{array}$ & $\begin{array}{c}213.34 \mathrm{abc} \\
(12.02 \pm 1.92)\end{array}$ \\
\hline Eristalinus aeneus & $\begin{array}{c}74.73 \mathrm{ab} \\
(7.95 \pm 1.41)\end{array}$ & $\begin{array}{c}119.59 c \\
(4.66 \pm 0.72)\end{array}$ \\
\hline E. arvorum & $\begin{array}{c}103.3 \mathrm{ab} \\
(11.05 \pm 1.34)\end{array}$ & $\begin{array}{c}182.91 \mathrm{abc} \\
(8.98 \pm 1.37)\end{array}$ \\
\hline Chi-Square & 22.88 & 39.39 \\
\hline$p$ & 0.01 & 0.00 \\
\hline
\end{tabular}

${ }^{*}$ Means of ranks in columns having different letters are statistically significant at $\alpha=0.05 .{ }^{* *}$ Mean values with standard errors are given in parenthesis.

\subsection{Single Visit Effectiveness of Pollinators}

There was a difference among the pollinator species in terms of number of pods produced per raceme (chi-square $=74.22, \mathrm{DF}=23, p=0.0001$ ), number of seeds per raceme (chi-square $=78.62, \mathrm{DF}=23, p=0.0001), 1000$ seed weight $($ chi-square $=49.60, \mathrm{DF}=11$, $p=0.0001$ ) and germination (chi-square $=47.08, \mathrm{DF}=11, p=0.0001$ ) among the tested pollinator species in a single visit. Single visit efficacy proved $M$. cephalotes as the most efficient insect pollinator followed by M. hera and Amegilla sp. while the flies (E. arvorum and E. aeneus) were the least efficient insect pollinators. Open pollination treatment resulted in highest number of pods per raceme, number of seeds per raceme, 1000 seed weight and germination. Hand tripping also proved less effective than the single visits of three most efficient bee species. No pod development was observed in pollination exclusion treatments (Table 5). 
Table 5. Comparison of means of ranks of single visit efficiency of abundant insect pollinator in terms of number of pods per flower, number of seeds set per flower, 1000 seed weight $(\mathrm{g})$ and germination.

\begin{tabular}{|c|c|c|c|c|}
\hline Pollinator Species & Number of Pods/Raceme & $\begin{array}{c}\text { Number of } \\
\text { Seeds/Raceme }\end{array}$ & $\begin{array}{c}1000 \\
\text { Seed Weight (g) }\end{array}$ & Germination (\%) \\
\hline Amegilla sp. & $\begin{array}{c}65.88 \mathrm{bc} * \\
(3.00 \pm 0.27)^{* *}\end{array}$ & $\begin{array}{c}69.81 \mathrm{bc} \\
(6.12 \pm 0.30)\end{array}$ & $\begin{array}{c}70.63 \mathrm{a} \\
(3.57 \pm 0.16)\end{array}$ & $\begin{array}{c}70.88 \mathrm{a} \\
(93.75 \pm 2.63)\end{array}$ \\
\hline Eucera sp. & $64.81 \mathrm{bc}$ & $\begin{array}{l}65.50 \mathrm{c} \\
\end{array}$ & $68.06 \mathrm{a}$ & $\begin{array}{c}70.88 \mathrm{a} \\
(9375+2\end{array}$ \\
\hline Nomia (Hoplonomia) sp. & $\begin{array}{c}56.75 \mathrm{~cd} \\
(2.50 \pm 0.19)\end{array}$ & $\begin{array}{c}56.69 \mathrm{c} \\
(4.80 \pm 0.35)\end{array}$ & $\begin{array}{c}64.63 \mathrm{a} \\
(3.42 \pm 0.17)\end{array}$ & $\begin{array}{c}56.25 \mathrm{ab} \\
(86.25 \pm 3.75)\end{array}$ \\
\hline Megachile cephalotes & $\begin{array}{c}71.88 \mathrm{~b} \\
(3.50 \pm 0.38)\end{array}$ & $\begin{array}{c}74.00 \mathrm{~b} \\
(7.63 \pm 0.94)\end{array}$ & $\begin{array}{c}64.75 \mathrm{a} \\
(3.45 \pm 0.21)\end{array}$ & $\begin{array}{c}78.88 \mathrm{a} \\
(97.50 \pm 1.64)\end{array}$ \\
\hline M. hera & $\begin{array}{c}65.88 \mathrm{bc} \\
(3.00 \pm 0.2)\end{array}$ & $\begin{array}{c}69.31 \mathrm{bc} \\
(6.12 \pm 0.44)\end{array}$ & $\begin{array}{c}68.00 \mathrm{a} \\
(3.53 \pm 0.15)\end{array}$ & $\begin{array}{c}56.25 \mathrm{~b} \\
(86.25 \pm 3.75)\end{array}$ \\
\hline Apis mellifera & $\begin{array}{c}20.50 \mathrm{fg} \\
(0.75 \pm 0.31)\end{array}$ & $\begin{array}{c}19.63 \text { ef } \\
(0.87 \pm 0.35)\end{array}$ & $\begin{array}{c}25.56 \mathrm{~cd} \\
(1.50 \pm 0.57)\end{array}$ & $\begin{array}{c}42.81 \mathrm{ab} \\
(77.50 \pm 5.26)\end{array}$ \\
\hline A. dorsata & $\begin{array}{c}36.81 \mathrm{e} \\
(1.63 \pm 0.26)\end{array}$ & $\begin{array}{c}35.69 \text { de } \\
(2.38 \pm 0.60)\end{array}$ & $\begin{array}{c}49.25 \mathrm{ab} \\
(3.08 \pm 0.18)\end{array}$ & $\begin{array}{c}23.19 \mathrm{bc} \\
(62.50 \pm 5.26)\end{array}$ \\
\hline A. florea & $\begin{array}{c}19.56 \mathrm{fg} \\
(0.75 \pm 0.25)\end{array}$ & $\begin{array}{c}21.25 \text { ef } \\
(1.00 \pm 0.39)\end{array}$ & $\begin{array}{c}19.94 \mathrm{~cd} \\
(1.56 \pm 0.48)\end{array}$ & $\begin{array}{c}31.63 \mathrm{bc} \\
(67.50 \pm 7.01)\end{array}$ \\
\hline Eristalinus aeneus & $\begin{array}{c}31.13 \text { ef } \\
(1.38 \pm 0.18)\end{array}$ & $\begin{array}{c}28.38 \mathrm{de} \\
(1.88 \pm 0.69)\end{array}$ & $\begin{array}{c}33.19 \mathrm{bc} \\
(1.92 \pm 0.58)\end{array}$ & $\begin{array}{c}29.63 \mathrm{bc} \\
(67.50 \pm 5.90)\end{array}$ \\
\hline E. arvorum & $\begin{array}{c}10.88 \mathrm{~g} \\
(0.25 \pm 0.16)\end{array}$ & $\begin{array}{c}10.63 \mathrm{f} \\
(0.13 \pm 0.13)\end{array}$ & $\begin{array}{c}12.31 \mathrm{~d} \\
(0.38 \pm 0.38)\end{array}$ & $\begin{array}{c}17.94 \mathrm{c} \\
(50.00 \pm 9.26)\end{array}$ \\
\hline Open pollination & $\begin{array}{c}92.50 \mathrm{a} \\
(13.25 \pm 0.88)\end{array}$ & $\begin{array}{c}92.50 \mathrm{a} \\
(21.75 \pm 1.42)\end{array}$ & $\begin{array}{c}58.38 \mathrm{ab} \\
(3.32 \pm 0.11)\end{array}$ & $\begin{array}{c}58.63 \mathrm{ab} \\
(87.50 \pm 3.66)\end{array}$ \\
\hline Hand pollination & $\begin{array}{c}45.44 \mathrm{de} \\
(2.00 \pm 0.19)\end{array}$ & $\begin{array}{c}38.63 \mathrm{~d} \\
(2.75 \pm 0.53)\end{array}$ & $\begin{array}{c}47.31 \mathrm{ab} \\
(3.10 \pm 0.18)\end{array}$ & $\begin{array}{c}45.06 \mathrm{ab} \\
(76.25 \pm 7.78)\end{array}$ \\
\hline Chi-square & 74.22 & 78.62 & 49.60 & 47.08 \\
\hline$p$ & $<0.0001$ & $<0.0001$ & $<0.0001$ & $<0.0001$ \\
\hline
\end{tabular}

${ }^{*}$ Means of ranks in columns having different letters are statistically significant at $\alpha=0.05 .{ }^{* *}$ Mean values with standard errors are given in parenthesis.

\section{Discussion}

Pollination efficiencies of leguminous crops (alfalfa and clover) differed greatly among pollinator species. In our study, honeybees were the highest in proportional abundance $(45 \%)$ in the first year, while honeybees and solitary bees $(35 \%)$ had the similar proportional abundance in the second year. However, in both years, syrphid flies were the least abundant. Some previous studies have also reported higher abundance $(85-98 \%)$ of solitary bees visiting lucerne flowers $[24,26,30,45,60]$. Moreover, from the same region, the higher abundance of honeybees and solitary bees has also been reported from other crops, i.e., canola [58], pumpkin [61]; luffa gourd [62] and radish [63]. In our study, during both years, bees from the family Megachilidae were more abundant (44-47\%) as compared to the other bee families. Worldwide, higher abundance of Megachile bees has been linked with the enhanced alfalfa seed production due to their higher pollination efficiency $[5,16,22,30,64]$.

Pollinator species varied in terms of tripping lucerne flowers and it was higher for solitary bees than the honeybees and flies. Among solitary bees, two Megachile sp. (M. cephalotes and M. hera) and Nomia (Hoplonomia) sp. were superior in tripping as compared to other most-abundant bee species. These tripping rates varied among pollinator species [24]. Some previous studies have also reported the better tripping efficiency of Nomia melanderi and other Megachile species (M. rotundata and $M$. abluta) on alfalfa flowers [15,45]. Social characters of Megachile sp. to collect pollen from the lucerne, its maximum foraging period coinciding with the lucerne blooming, also enable it to trip the lucerne flowers more efficiently $[65,66]$. Since most of the female solitary bees are pollen foragers, they exploit flower by ensuring tripping of Medicago flowers [31]. Moreover, tripping efficiency of Nomia sp. is due to its buzz pollination character, production of several generations in a year, high abundance and foraging time synchrony with lucerne blooming [25]. Tripping varied with time of day; our results are in line with the previous studies illustrating that visits of bees peaked from 10:00 am to 14:00 pm, and this period coincided with the complete release of the pollen [32]. Moreover, all the pollinators were at their peak abundance at 11:00 am to $14: 00 \mathrm{pm}$ during both years. This is attributed to the pollinators' activity, which is predicted 
by the time of anthesis, the time when a large amount of nectar and pollen resources are available [33].

In our study, both managed and wild honeybees were least effective (4-10\%) in terms of tripping the flowers. Some previous studies have also reported the inefficiency of managed honeybees in tripping the alfalfa flowers due to different reasons. First, honeybee workers quickly learn to access the nectar without tripping the flower due to their side feeding habit that minimizes the chances of tripping lucerne flowers $[31,67]$. Second, lucerne pollen is lacking the essential amino acid (isoleucine), which means honeybees suffer protein stress when only pollinating lucerne [30]. Third, some adaptive behavioral characters also lead honeybees towards poor tripping, resulting in 1\% tripping in open field conditions $[29,68,69]$ and only $22 \%$ under caged experiments [15]. Moreover, tripping inefficiency ( $5 \%$ of the visited flowers) of wild honeybees (A. dorsata, A. florea) has also been reported $[24,70]$.

Similarly, syrphid flies (E. aeneus and E. arvorum) also proved ineffective in terms of tripping lucerne flowers. Previously, tripping inefficiency of syrphid fly (Eristalinus tenax) and other flies (Calliphora vicina and Lucilia sericata) has also been reported from Medicago pollination [71]. Syrphid flies feed mainly on nectar and often return to feed on previously visited flowers, despite being caged and restricted in space or resources [72-74].

In the current study, solitary bees harvested more pollen on a single visit than those of honeybees and flies. The two Megachile species (M. cephalotes and M. hera) harvested the highest number of pollen grains followed by $A$. mellifera and $A$. dorsata. This pollen harvest indicates a passive pollen load by the bees on a single visit. The pollen-foraging individuals can be more effective pollinators than the mere nectar foragers $[75,76]$ and pollen foraging leads to greater tripping of alfalfa flowers [77,78]. In our study, Nomia sp. and Eucera sp. were less efficient in terms of harvesting pollen grains although their tripping efficiency was equivalent to the other high pollen harvesting species. Contrarily, a previous study reported high pollen harvest (2100) for $N$. melanderi after their 15 visits in $M$. sativa [15].

Solitary bees proved best in terms of single visit pod set per raceme and seed setting as compared to honeybees and flies. Among the solitary bees, M. cephalotes resulted in maximum pods and seed set followed by M. hera and Amegilla sp. Probabilities of pod and seed setting are higher for the insect pollinators with higher tripping rates [15]. Pod setting done by Nomia (Hoplonomia) sp. and M. hera was 66 and 62\%, respectively. Previously, a single study reported effectiveness of $M$. rotundata and $N$. melanderi) as most efficient in terms of single-visit pod set efficiency in the range of 40-57\% [15]. Megachile rotundata and $N$. melanderi are the intensively managed bees on commercial level for lucerne crop [20]. Moreover, from South Punjab region, the effectiveness of other solitary bees in terms of single-visit seed/fruit set have been reported for other crops, i.e., canola [58], bitter gourd [56], pumpkin [61], luffa gourd [62] and falsa [79].

The effect of solitary pollinating insects was remarkable and confirms the preponderant role of solitary bee pollinators on seed set of Medicago flowers whereas honeybees were confirmed to be poor pollinators of this crop, which collect pollen from Medicago under certain circumstances. Pollen-gathering honeybees are usually better pollinators than nectar-gathering honeybees, which often forage by 'side-working' the flowers. During those visits, the bee does not make contact with the stigmas. Solitary bees, on the other hand, usually work the flowers from the tip, irrespective of foraging activity, almost always contacting the anthers and stigmas [80-83]. Moreover, flies (E. aeneus and E. arvorum) were also ineffective in their single-visit seed set in both the years. Seed setting of flies E. tenax (Syrphidae), C. vicina and L. sericata (Calliphoridae) were lower because of insufficient pollen transfer and pollen adhering to their bodies [71].

In open pollination, seed set was $85 \%$ higher as compared to the self-pollination ( $0 \%$ ). Self-pollination is not fruitful in the case of lucerne seed formation due to the abortion of seeds [15]. Previously, open pollination along with solitary bees produced significantly more seeds as compared to honeybees and pollination-exclusion flowers [18,26,84]. Moreover, open pollination also produced $87 \%$ higher seed set than the hand-tripped flowers. 
Previous hand-pollination studies in alfalfa have shown that hand-tripped flowers generally produce pods with one to two seeds per pod [26,71,85-87].

\section{Conclusions}

In conclusion, the solitary bees ( $M$. cephalotes, M. hera, Amegilla sp.) proved to be the most efficient pollinators for lucerne seed production. Conservation of these most-efficient bees (through provisioning of foraging and nesting resources) can lead to sustainable alfalfa seed production. Future studies should focus on exploring the population threshold of these bee species for better pollination and seed production in lucerne.

Author Contributions: S.S. and M.A. developed the hypothesis and planned the study. A.R. conducted the experiments and recorded the data. M.H.N.T. analyzed the data and wrote the manuscript along with other authors. All authors have read and agreed to the published version of the manuscript.

Funding: Authors are thankful to Higher Education Commission, Pakistan for providing funds to conduct this study through Indigenous 5000 PhD Fellowship Phase-II, Batch-V.

Institutional Review Board Statement: Not applicable.

Informed Consent Statement: Not applicable.

Data Availability Statement: Not applicable.

Acknowledgments: Authors are grateful to Asif Sajjad (Department of Entomology, Islamia University, Bahawalpur, Pakistan) and Anjum Shahzad (National Insect museum, National Agriculture Research center, Islamabad) for help in identification of pollinator species.

Conflicts of Interest: The authors declare no conflict of interest.

\section{References}

1. Ollerton, J.; Winfree, R.; Tarrant, S. How many flowering plants are pollinated by animals? Oikos 2011, 120, 321-326. [CrossRef]

2. Klein, A.-M.; Vaissiere, B.E.; Cane, J.H.; Steffan-Dewenter, I.; Cunningham, S.A.; Kremen, C.; Tscharntke, T. Importance of pollinators in changing landscapes for world crops. Proc. R. Soc. B Biol. Sci. 2007, 274, 303-313. [CrossRef] [PubMed]

3. Potts, S.G.; Imperatriz-Fonseca, V.; Ngo, H.T.; Aizen, M.A.; Biesmeijer, J.C.; Breeze, T.D.; Dicks, L.V.; Garibaldi, L.A.; Hill, R.; Settele, J. Safeguarding pollinators and their values to human well-being. Nature 2016, 540, 220-229. [CrossRef]

4. Ollerton, J. Pollinator Diversity: Distribution, Ecological Function, and Conservation. Annu. Rev. Ecol. Evol. Syst. 2017, 48, 353-376. [CrossRef]

5. Breazeale, D.; Fernandez, G.; Narayanan, R. Modeling pollination factors that influence alfalfa seed yield in north-central Nevada. J. Cent. Eur. Agric. 2008, 9, 107-116. Available online: https://hrcak.srce.hr/24896 (accessed on 10 November 2021).

6. Klein, A.-M.; Boreux, V.; Fornoff, F.; Mupepele, A.-C.; Pufal, G. Relevance of wild and managed bees for human well-being. Curr. Opin. Insect Sci. 2018, 26, 82-88. [CrossRef] [PubMed]

7. Iannucci, A.; Di Fonzo, N.; Martiniello, P. Alfalfa (Medicago sativa L.) seed yield and quality under different forage management systems and irrigation treatments in a Mediterranean environment. Field Crop. Res. 2002, 78, 65-74. [CrossRef]

8. Abusuwar, A.O.; Elhassan, B. Effect of Water Quality and Weeding on Yield and Quality of Three Alfalfa ('Medicago sativa L.') Cultivars. Aust. J. Crop Sci. 2009, 3, 315. [CrossRef]

9. Keivani, M.; Ramezanpour, S.s.; Soltanloo, H.; Choukan, R.; Naghavi, M.; Ranjbar, M. Genetic Diversity Assessment of Alfalfa ('Medicago sativa' L.) Populations Using AFLP Markers. Aust. J. Crop Sci. 2010, 4, 491. [CrossRef]

10. Wang, X.; Yang, X.; Chen, L.; Feng, G.; Zhang, J.; Jin, L. Genetic diversity among alfalfa (Medicago sativa L.) cultivars in Northwest China. Acta Agric. Scand. Sect. B-Soil Plant Sci. 2011, 61, 60-66. [CrossRef]

11. Hua, J.; Yufen, B.; Jun, Z. A study on alfalfa pollinating mechanism and relationship of pollinating insects. Cao Ye Ke Xue Pratacultural Sci. Caoye Kexue 2003, 20, 1-6.

12. Radović, J.; Sokolović, D.; Marković, J. Alfalfa-most important perennial forage legume in animal husbandry. Biotechnol. Anim. Husb. 2009, 25, 465-475. Available online: https://scindeks.ceon.rs/article.aspx?artid=1450-91560906465R (accessed on 10 November 2021). [CrossRef]

13. Russelle, M.P. Alfalfa: After an 8000-year journey, the "Queen of Forages" stands poised to enjoy renewed popularity. Am. Sci. 2001, 89, 252-261. Available online: http:/ / www.jstor.org/stable/27857472 (accessed on 10 November 2021). [CrossRef]

14. Pedersen, M.W. Lucerne Pollination. Bee World 2002, 42, 145-149. [CrossRef]

15. Cane, J.H. Pollinating bees (Hymenoptera: Apiformes) of U.S. alfalfa compared for rates of pod and seed set. J. Econ. Entomol. 2002, 95, 22-27. [CrossRef] 
16. Brunet, J.; Zhao, Y.; Clayton, M.K. Linking the foraging behavior of three bee species to pollen dispersal and gene flow. PLoS ONE 2019, 14, e0212561. [CrossRef] [PubMed]

17. Ambaw, M.; Workiye, M. Evaluation and demonstration of the roll of honey bees on seed yield of alfalfa (Medicago sativa FL77) in Kulumsa, Ethiopia. J. Entomol. Zool. Stud. 2020, 8, 2269-2272, ISSN 2349-6800.

18. Kumar, N.K.S.V. Studies on insect fauna of lucerne Medicago sativa and their impact on seed and forage yield in lucerne Medicago sativa. In Proceedings of the International Grassland Congress Proceedings, New Delhi, India, 20-24 November 2015. Available online: https:/ / uknowledge.uky.edu/cgi/viewcontent.cgi?article=1651\&context=igc (accessed on 12 March 2021).

19. Bell, A.M.C.; Haigh, A.M. Pollination of Greenhouse Tomatoes by the Australian Bluebanded Bee Amegilla (Zonamegilla) holmesi (Hymenoptera: Apidae). J. Econ. Entomol. 2006, 99, 437-442. [CrossRef]

20. Stephen, W.P. Solitary bees in North America: A perspective. In For Non-Native Crops, Whence Pollinators of the Future? Entomological Society of America; The National Academies Press: Washington, DC, USA, 2003; pp. 41-66. [CrossRef]

21. Cecen, S.; Gurel, F.; Karaca, A. Impact of honeybee and bumblebee pollination on alfalfa seed yield. Acta Agric. Scand. Sect. B-Soil Plant Sci. 2008, 58, 77-81. [CrossRef]

22. Bosch, J.; Kemp, W.P. Alfalfa leafcutting bee population dynamics, flower availability, and pollination rates in two Oregon alfalfa fields. J. Econ. Entomol. 2005, 98, 1077-1086. [CrossRef]

23. Losey, J.E.; Vaughan, M. The economic value of ecological services provided by insects. Bioscience 2006, 56, 311-323. [CrossRef]

24. Brunet, J.; Stewart, C.M. Impact of bee species and plant density on alfalfa pollination and potential for gene flow. Psyche 2010, 2010, 201858. [CrossRef] [PubMed]

25. Hogendoorn, K.; Keller, M. Native Australian Bees as Potential Pollinators of Lucerne; RIRDC Publication: Canberra, Australia, 2012; ISSN 1440-6845. Available online: https:/ / www.agrifutures.com.au/wp-content/uploads/publications/12-048.pdf (accessed on 5 May 2021).

26. Chen, M.; Zhao, X.Y.; Zuo, X.A. Pollinator activity and pollination success of Medicago sativa L. in a natural and a managed population. Ecol. Evol. 2018, 8, 9007-9016. [CrossRef] [PubMed]

27. Donovan, S.E.; Hall, M.J.R.; Turner, B.D.; Moncrieff, C.B. Larval growth rates of the blowfly, Calliphora vicina, over a range of temperatures. Med. Vet. Entomol. 2006, 20, 106-114. [CrossRef] [PubMed]

28. Howlett, B.G.; Donovan, B.J. A review of New Zealand's deliberately introduced bee fauna: Current status and potential impacts. N. Z. Entomol. 2010, 33, 92-101. [CrossRef]

29. Phillips, B.B.; Williams, A.; Osborne, J.L.; Shaw, R.F. Shared traits make flies and bees effective pollinators of oilseed rape (Brassica napus L.). Basic Appl. Ecol. 2018, 32, 66-76. [CrossRef]

30. Pitts-Singer, T.L.; Cane, J.H. The alfalfa leafcutting bee, Megachile rotundata: The world's most intensively managed solitary bee. Annu. Rev. Entomol. 2011, 56, 221-237. [CrossRef]

31. Goodwin, M. Pollination of crops in Australia and New Zealand. In Rural Industries Research and Development Corporation (Australia); Plant \& Food Research: Ruakura, New Zealand, 2012; ISBN 9781742544021. Available online: https://www. agrifutures.com.au/wp-content/uploads/publications/12-059.pdf (accessed on 25 May 2021).

32. Chen, M.; Zuo, X.-A. Pollen limitation and resource limitation affect the reproductive success of Medicago. BMC Ecol. 2018, 18, 28. [CrossRef]

33. Varassinl, I.G.; Trigj, J.R.; Sazimai, M. The role of nectar production, flower pigments and odour in the pollination of four species of Passiflora (Passifloraceae) in south-eastern Brazil. Bot. J. Linn. Soc. 2001, 136, 139-152. [CrossRef]

34. Sinu, P.A.; Shivanna, K.R. Pollination ecology of cardamom (Elettaria cardamomum) in the Western Ghats, India. J. Trop. Ecol. 2007, 23, 493-496. [CrossRef]

35. Rodríguez-Cabal, M.A.; Aizen, M.A.; Novaro, A.J. Habitat fragmentation disrupts a plant-disperser mutualism in the temperate forest of South America. Biol. Conserv. 2007, 139, 195-202. [CrossRef]

36. Nayak, K.G.; Davidar, P. Pollinator limitation and the effect of breeding systems on plant reproduction in forest fragments. Acta Oecologica 2010, 36, 191-196. [CrossRef]

37. O'Neill, K.M.; O'Neill, R.P.; Blodgett, S.; Fultz, J. Composition of pollen loads of Megachile rotundata in relation to flower diversity (Hymenoptera: Megachilidae). J. Kansas Entomol. Soc. 2004, 77, 619-625. [CrossRef]

38. Ne'eman, G.; Jürgens, A.; Newstrom-Lloyd, L.; Potts, S.G.; Dafni, A. A framework for comparing pollinator performance: Effectiveness and efficiency. Biol. Rev. 2010, 85, 435-451. [CrossRef]

39. Rader, R.; Howlett, B.G.; Cunningham, S.A.; Westcott, D.A.; Edwards, W. Spatial and temporal variation in pollinator effectiveness: Do unmanaged insects provide consistent pollination services to mass flowering crops? J. Appl. Ecol. 2012, 49, 126-134. [CrossRef]

40. Garibaldi, L.A.; Steffan-Dewenter, I.; Winfree, R.; Aizen, M.A.; Bommarco, R.; Cunningham, S.A.; Kremen, C.; Carvalheiro, L.G.; Harder, L.D.; Afik, O. Wild pollinators enhance fruit set of crops regardless of honey bee abundance. Science 2013, 339, 1608-1611. [CrossRef]

41. Ballantyne, G.; Baldock, K.C.R.; Willmer, P.G. Constructing more informative plant-pollinator networks: Visitation and pollen deposition networks in a heathland plant community. Proc. R. Soc. B Biol. Sci. 2015, 282, 20151130. [CrossRef] [PubMed]

42. King, C.; Ballantyne, G.; Willmer, P.G. Why flower visitation is a poor proxy for pollination: Measuring single-visit pollen deposition, with implications for pollination networks and conservation. Methods Ecol. Evol. 2013, 4, 811-818. [CrossRef]

43. Bruckman, D.; Campbell, D.R. Floral neighborhood influences pollinator assemblages and effective pollination in a native plant. Oecologia 2014, 176, 465-476. [CrossRef] [PubMed] 
44. Barrios, B.; Pena, S.R.; Salas, A.; Koptur, S. Butterflies visit more frequently, but bees are better pollinators: The importance of mouthpart dimensions in effective pollen removal and deposition. AoB Plants 2016, 8, plw001. [CrossRef] [PubMed]

45. Wang, X.; Liu, H.; Huang, L.; Zhang, S.; Deng, Z.; Li, J. Biodiversity of wild alfalfa pollinators and their temporal foraging characters in Hexi Corridor, Northwest China. Entomol. Fenn. 2012, 23, 4-12. [CrossRef]

46. Ahmed, N.; Umer, A.; Ali, M.A.; Iqbal, J.; Mubashir, M. Micronutrients status of mango (Mangifera indica) orchards in Multan region, Punjab, Pakistan, and relationship with soil properties. Open Agric. 2020, 5, 271-279. [CrossRef]

47. Abbas, F.; Ahmad, A.; Safeeq, M.; Ali, S.; Saleem, F.; Hammad, H.M.; Farhad, W. Changes in precipitation extremes over arid to semiarid and subhumid Punjab, Pakistan. Theor. Appl. Climatol. 2014, 116, 671-680. [CrossRef]

48. Abbas, F. Analysis of a historical (1981-2010) temperature record of the Punjab province of Pakistan. Earth Interact. 2013, 17, 1-23. [CrossRef]

49. Ahmad, I.; Bibi, F.; Ullah, H.; Munir, T.M. Mango fruit yield and critical quality parameters respond to foliar and soil applications of zinc and boron. Plants 2018, 7, 97. [CrossRef]

50. Undersander, D.; Cosgrove, D.; Cullen, E.; Rice, M.E.; Renz, M.; Sheaffer, C.; Shewmaker, G.; Sulc, M. Alfalfa Management Guide; American Society of Agronomy, Wiley Online Library: Madison, WC, USA, 2011; ISBN 0891181997. Available online: https: / / www.agronomy.org/files/publications/alfalfa-management-guide.pdf (accessed on 24 April 2021).

51. Bauer, A.A.; Clayton, M.K.; Brunet, J. Floral traits influencing plant attractiveness to three bee species: Consequences for plant reproductive success. Am. J. Bot. 2017, 104, 772-781. [CrossRef] [PubMed]

52. Karar, H.; Bashir, M.A.; Khaliq, A.; Ali, M.J.; Atalla Alajmi, R.; Metwally, D.M. Stink bug Agonoscelis spp. (Heteroptera: Pentatomidae)-An emerging threat for seed production in alfalfa crop (Medicago sativa L.) and their successful management. Saudi J. Biol. Sci. 2021, 28, 3477-3482. [CrossRef] [PubMed]

53. Mazeed, A.; Zidan, E.; Abd El-latif, A. Role of Pollinators on Egyptian Clover Pollination with Special Reference To Honeybee At Sohag Governorate, Egypt. Arab Univ. J. Agric. Sci. 2019, 27, 853-860. [CrossRef]

54. Aguilar, A.C.; Maria Parra Tabla, V. Importance of conserving alternative pollinators: Assessing the pollination efficiency of the squash bee, Peponapis limitaris in Cucurbita moschata (Cucurbitaceae). J. Insect Conserv. 2000, 4, 203-210. [CrossRef]

55. Tidke, J.A.; Thorat, S.B. Observations on reproductive biology of Madhuca longifolia (Koen) Maccbr. Int. J. Reprod. Biol. 2011, 3, 1-8.

56. Saeed, S.; Malik, S.A.; Dad, K.; Sajjad, A.; Ali, M. In search of the best native pollinators for bitter gourd (Momordica charantia L.) pollination in Multan, Pakistan. Pak. J. Zool. 2012, 44, 1633-1641.

57. Rader, R.; Howlett, B.G.; Cunningham, S.A.; Westcott, D.A.; Newstrom-Lloyd, L.E.; Walker, M.K.; Teulon, D.A.J.; Edwards, W. Alternative pollinator taxa are equally efficient but not as effective as the honeybee in a mass flowering crop. J. Appl. Ecol. 2009, 46, 1080-1087. [CrossRef]

58. Ali, M.; Saeed, S.; Sajjad, A.; Whittington, A. In search of the best pollinators for canola (Brassica napus L.) production in Pakistan. Appl. Entomol. Zool. 2011, 46, 353-361. [CrossRef]

59. Islam, M.M.; Ahmed, I.; Akter, N.; Rahman, M.M.; Rahman, M.L.; Sultana, N. Seed viability and vigour tests in Jute (Corchorus spp.). J. Agron. 2002, 1, 44-46, ISSN 1812-5417. [CrossRef]

60. Wang, X.; Liu, H.; Li, X.; Song, Y.; Chen, L.; Jin, L. Correlations between environmental factors and wild bee behavior on alfalfa (Medicago sativa) in Northwestern China. Environ. Entomol. 2009, 38, 1480-1484. [CrossRef]

61. Ali, M.; Saeed, S.; Sajjad, A.; Bashir, M.A. Exploring the best native pollinators for pumpkin (Cucurbita pepo) production in Punjab, Pakistan. Pak. J. Zool. 2014, 46, 531-539.

62. Ali, M.; Saeed, S.; Sajjad, A. Pollen Deposition Is More Important than Species Richness for Seed Set in Luffa Gourd. Neotrop. Entomol. 2016, 45, 499-506. [CrossRef] [PubMed]

63. Zameer, S.U.; Bilal, M.; Fazal, M.I.; Sajjad, A. Foraging behavior of pollinators leads to effective pollination in radish Raphanus sativus L. Asian J. Agric. Biol. 2017, 5, 221-227.

64. Darrach, M.; Page, S. Statistical Overview of the Canadian Honey and Bee Industry and the Economic Contribution of Honey Bee Pollination 2013-2014. Horticulture and Cross Sectoral Division Report. 2016. Available online: https://agriculture.canada.ca/ sites/default/files/legacy/resources/prod/doc/pdf/honey_2016-eng.pdf (accessed on 20 September 2021).

65. Bohart, G.E. Management of wild bees for the pollination of crops. Annu. Rev. Entomol. 1972, 17, 287-312. [CrossRef]

66. Anderson, D. Improving Lucerne Pollination with Leafcutter Bees Stage 2. Rural Industries Research and Development Corporation. 2006. Available online: https://moam.info/improving-lucerne-pollination-with-leafcutter-bees-agrifuturesaustralia_5b805610097c47cf768b473a.html (accessed on 30 January 2009).

67. Palmer-Jones, T.; Forster, I.W. Observations on the Pollination of Lucerne (Medicago sativa Linn.). N. Z. J. Agric. Res. 1965, 8, 340-349. [CrossRef]

68. Brodie, B.; Gries, R.; Martins, A.; VanLaerhoven, S.; Gries, G. Bimodal cue complex signifies suitable oviposition sites to gravid females of the common green bottle fly. Entomol. Exp. Appl. 2014, 153, 114-127. [CrossRef]

69. Mohr, R.M.; Tomberlin, J.K. Development and validation of a new technique for estimating a minimum postmortem interval using adult blow fly (Diptera: Calliphoridae) carcass attendance. Int. J. Legal Med. 2015, 129, 851-859. [CrossRef] [PubMed]

70. Dylewska, M.; Jablonski, B.; Sowa, S.; Bilinski, M.; Wrona, S. An attempt of determination of the number of bees (Hym., Apoidea) needed for adequate pollination of alfalfa. Pol. Pismo Entomol 1970, 40, 371-398, ISSN 0032-3780.

71. Juan, A.; Petanidou, T.; Crespo, M.B.; Pe, C. The reproductive ecology of Medicago citrina (Font Quer) Greuter (Leguminosae): A bee-pollinated plant in Mediterranean islands where bees are absent. Plant Syst. Evol. 2003, 241, 29-46. [CrossRef] 
72. Jarlan, A.; De Oliveira, D.; Gingras, J. Pollination by Eristalis tenax (Diptera: Syrphidae) and seed set of greenhouse sweet pepper. J. Econ. Entomol. 1997, 90, 1646-1649. [CrossRef]

73. Mallinger, R.E.; Bradshaw, J.; Varenhorst, A.J.; Prasifka, J.R. Native solitary bees provide economically significant pollination services to confection sunflowers (Helianthus annuus L.) (Asterales: Asteraceae) grown across the northern Great Plains. J. Econ. Entomol. 2019, 112, 40-48. [CrossRef]

74. Cook, D.F.; Voss, S.C.; Finch, J.T.D.; Rader, R.C.; Cook, J.M.; Spurr, C.J. The Role of Flies as Pollinators of Horticultural Crops: An Australian Case Study with Worldwide Relevance. Insects 2020, 11, 341. [CrossRef] [PubMed]

75. Bader, K.L.; Anderson, S.R. Effect of Pollen and Nectar Collecting Honeybees on the Seed Yield of Birdsfoot trefoil, Lotus corniculatus L. 1. Crop Sci. 1962, 2, 148-149. [CrossRef]

76. Cane, J.H.; Schiffhauer, D. Pollinator genetics and pollination: Do honey bee colonies selected for pollen-hoarding field better pollinators of cranberry Vaccinium macrocarpon? Ecol. Entomol. 2001, 26, 117-123. [CrossRef]

77. Wilson, P.; Thomson, J.D. Heterogeneity among floral visitors leads to discordance between removal and deposition of pollen. Ecology 1991, 72, 1503-1507. [CrossRef]

78. Batra, S.W.T. Comparative efficiency of alfalfa pollination by Nomia melanderi, Megachile rotundata, Anthidium florentinum and Pithitis smaragdula (Hymenoptera: Apoidea). J. Kansas Entomol. Soc. 1976, 49, 18-22. Available online: https://www.jstor.org/ stable/25082782 (accessed on 20 September 2021).

79. Akram, W.; Sajjad, A.; Ali, S.; Mujtaba, G.; Ali, M.; Ahmad, A. Pollination of Grewia asiatica (Malvaceae) by Megachile cephalotes (Hymenoptera:Megachilidae): Male vs. Female Pollination. Sociobiology 2019, 66, 467-474. [CrossRef]

80. Vicens, N.; Bosch, J. Pollinating efficacy of Osmia cornuta and Apis mellifera (Hymenoptera: Megachilidae, Apidae) on 'red Delicious' apple. Environ. Entomol. 2000, 29, 235-240. [CrossRef]

81. Thomson, J.D.; Goodell, K. Pollen removal and deposition by honeybee and bumblebee visitors to apple and almond flowers. J. Appl. Ecol. 2001, 38, 1032-1044. Available online: https://www.jstor.org/stable/827241 (accessed on 10 November 2021). [CrossRef]

82. Monzón, V.H.; Bosch, J.; Retana, J. Foraging behavior and pollinating effectiveness of Osmia cornuta (Hymenoptera: Megachilidae) and Apis mellifera (Hymenoptera: Apidae) on "Comice" pear. Apidologie 2004, 35, 575-585. [CrossRef]

83. Cane, J.H. Pollination potential of the bee Osmia aglaia for cultivated red raspberries and blackberries (Rubus: Rosaceae). HortScience 2005, 40, 1705-1708. [CrossRef]

84. Pecetti, L.; Tava, A.; Felicioli, A.; Pinzauti, M.; Piano, E. Effect of three volatile compounds from lucerne flowers on their attractiveness towards pollinators. Bull. Insectology 2002, 55, 21-27. [CrossRef]

85. Riday, H.; Reisen, P.; Raasch, J.A.; Santa-martinez, E.; Brunet, J. Selfing Rate in an Alfalfa Seed Production Field Pollinated with Leafcutter Bees. Crop Sci. 2015, 55, 1087-1095. [CrossRef]

86. Bradner, N.R.; Frakes, R. V Crossed and Selfed Seeds within Alfalfa Pods Produced by Endemic Pollinators 1. Crop Sci. 1964, 4, 111. [CrossRef]

87. Viands, D.R.; Sun, P.; Barnes, D.K. Pollination control: Mechanical and sterility. Alfalfa Alfalfa Improv. 1988, 29, 931-960. [CrossRef] 